\title{
Decapod crustaceans from the Cretaceous (Aptian-Albian) San Gil Group in the Villa de Leyva section, central Colombia
}

\author{
Hermann D. Bermúdez, Arley de J. Gómez-Cruz, Matúš Hyžný, Josep A. Moreno-Bedmar, \\ Ricardo Barragán, Mario Moreno Sánchez, and Francisco J. Vega
}

With 8 figures

\begin{abstract}
Bermúdez, H.D., Gómez-Cruz, A. de J., Hyžný, M., Moreno-Bedmar, J.A., Barragán, R., Moreno SÁnchez, M. \& VegA, F.J. (2013): Decapod crustaceans from the Cretaceous (Aptian-Albian) San Gil Group in the Villa de Leyva section, central Colombia. - N. Jb. Geol. Paläont. Abh., 267: 255-272; Stuttgart.
\end{abstract}

\begin{abstract}
Abundant concretions at two localities in central Colombia where the San Gil Inferior and San Gil Superior formations are exposed, have yielded numerous crustacean individuals, comprising one new genus Rathbunassa n. gen. (Callianassidae), two new species Joeranina colombiana $\mathrm{n}$. sp., Planocarcinus johnjagti n. sp., and three further species. The following taxa are recorded: ?Paraxiopsis sp. (Axiidae), Rathbunassa aquilae (RATHBun, 1935) n. comb. (Callianassidae), Joeranina kerri (Luque, Feldmann, Schweitzer, Jaramillo \& Cameron, 2012) n. comb., Joeranina colombiana $\mathrm{n}$. sp. (Palaeocorystidae), Cenomanocarcinus vanstraeleni STEnzel, 1945 (Cenomanocarcinidae), and Planocarcinus johnjagti n. sp. (Necrocarcinidae). Based on ammonite evidence, the locality within the San Gil Inferior Formation is considered to be of late Aptian age, while the one exposing the San Gil Superior Formation is of middle Albian date. Joeranina kerri is found at both localities; in contrast Planocarcinus johnjagti n. sp. occurs exclusively in the upper Aptian, while the remainder of species are all from the middle Albian locality. The taxa reported herein add important data to the palaeobiodiversity and distribution of Cretaceous decapod crustaceans.
\end{abstract}

Key words: Crustacea, Axiidea, Palaeocorystoidea, new taxa, Aptian, Albian, Colombia.

\section{Introduction}

Several concretion-rich horizons occurring near the Cucaita-Villa de Leyva motorway in central Colombia (Fig. 1) are part of the type sections of the San Gil Inferior and San Gil Superior formations of AptianAlbian age (Fig. 2). Two localities have been sampled by us; one (locality 1) exposing the middle portion of the San Gil Inferior Formation, the other (locality 2) representing the upper portion of the San Gil Superior Formation. The siliceous concretions vary in diameter from a few millimetres to up to $5 \mathrm{~cm}$. They contain callianassoid and palaeocorystoid crustaceans and a few ammonites, bivalves and gastropods. From the same level within the San Gil Superior Formation, VegA et al. (2010) recorded a single specimen of Cenomanocarcinus vanstraeleni and considered it of late Albian age. Based on ammonite biostratigraphy discussed in the present paper, crustacean-bearing strata of the San Gil Inferior Formation at locality 1 are here assigned to the upper Aptian. Crustacean-producing levels of the San Gil Superior Formation are of middle Albian age, which means that the range of Cenomanocarcinus vanstraeleni can be extended. 


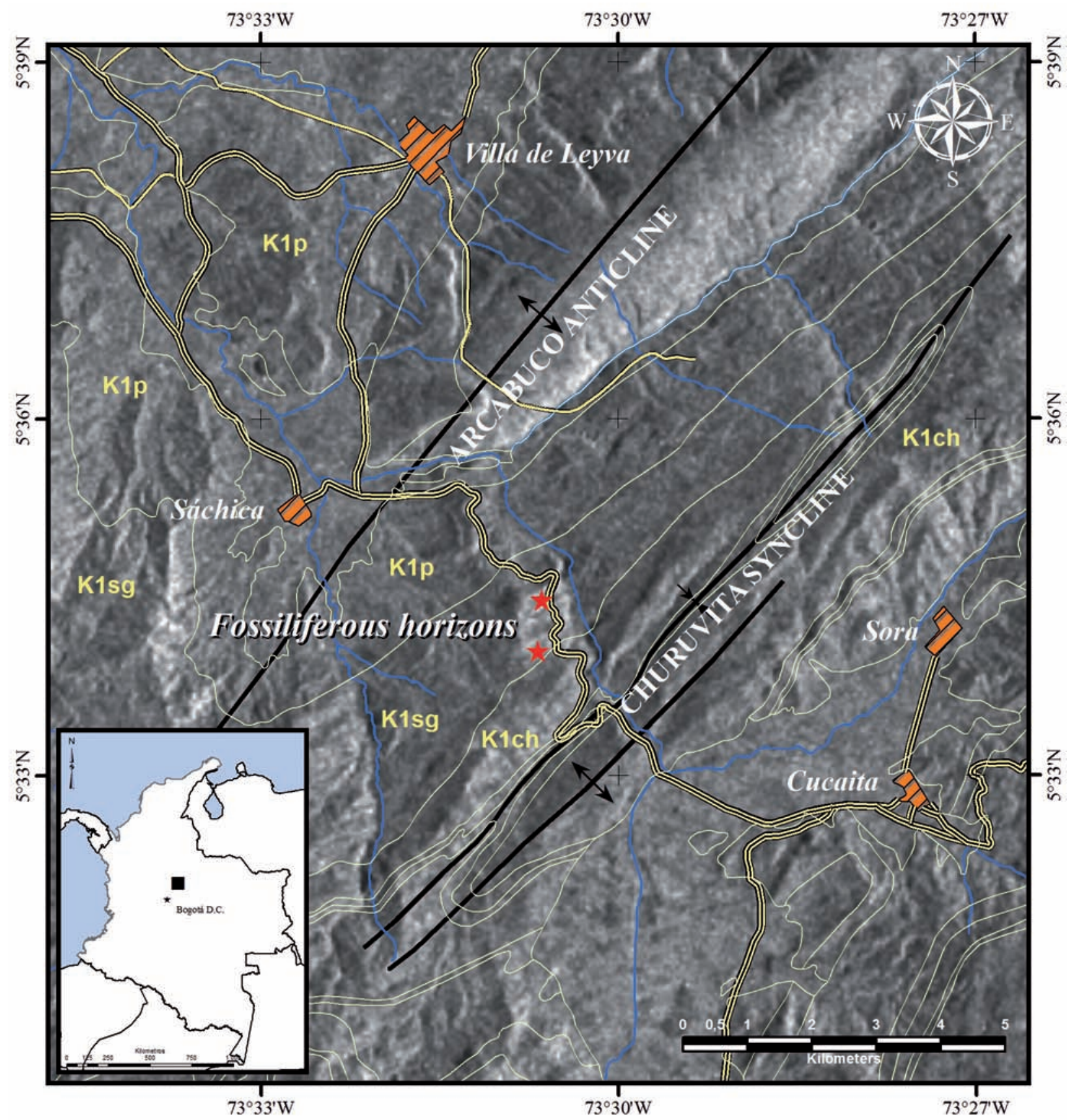

Fig. 1. Locality map of the two fossiliferous horizons recorded herein, south of Villa de Leyva, central Colombia. K1ch = Churuvita Formation, K1p = Paja Formation, K1sg = San Gil Group (San Gil Inferior and San Gil Superior formations).

The San Gil Inferior Formation is subdivided into four parts. The lower portion, A, comprises $140 \mathrm{~m}$ of grey arenaceous and muscovitic, mottled red to yellow oxidized claystones with argillaceous nodules and some beds of micaceous and muddy sandstones. Part B includes about $200 \mathrm{~m}$ of massive, arenaceous and fossiliferous beds of limestones, interbedded with micaceous claystones or siltstones, while portion $\mathrm{C}$ is 


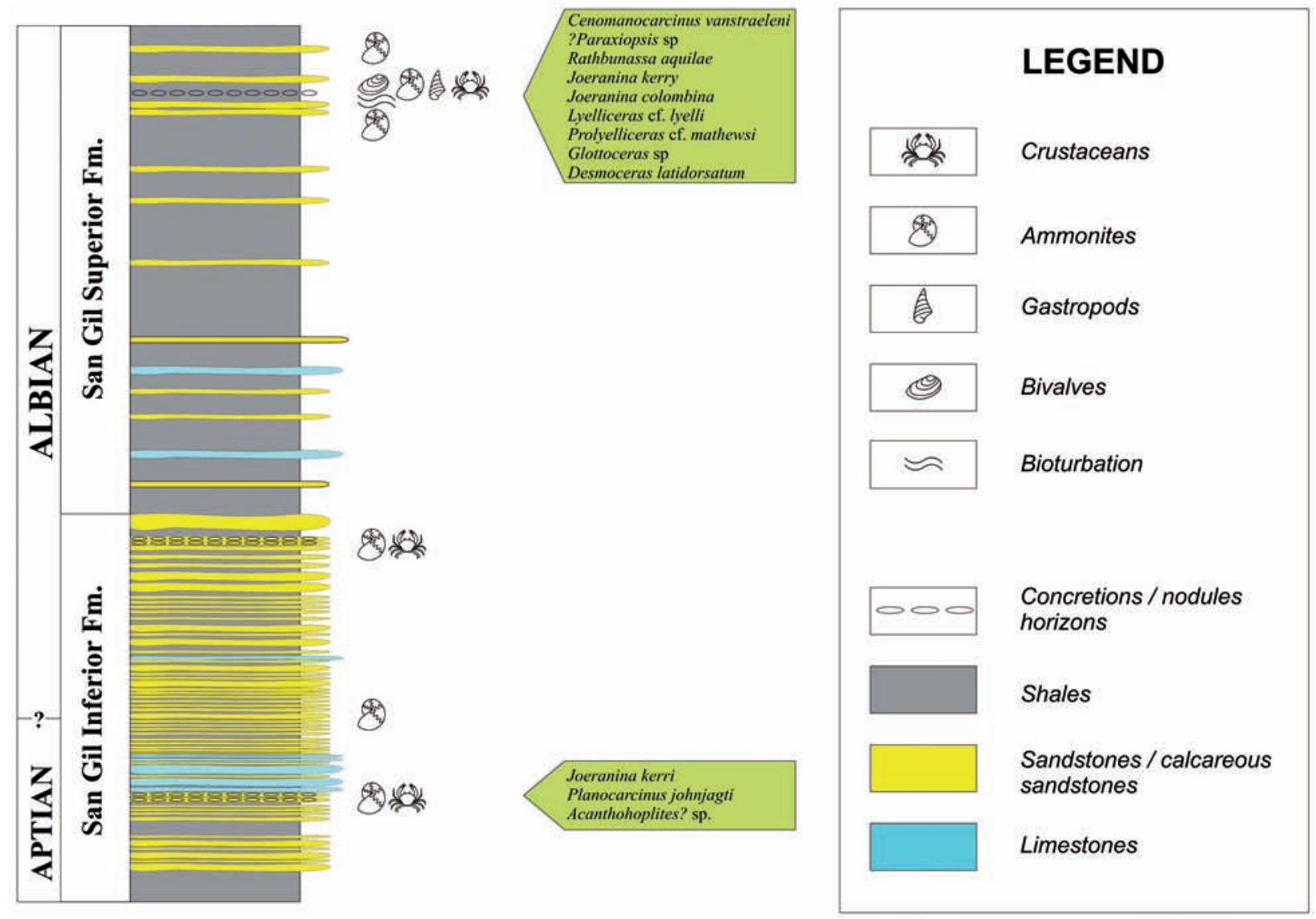

Fig. 2. Composite stratigraphic log of the localities studied, with indications of fossiliferous horizons.

composed of $25 \mathrm{~m}$ of very thick beds of grey muscovitic sandstones, interbedded with dark grey shales. The upper part, D, comprises $125 \mathrm{~m}$ of alternating thick calcareous beds, grey shales or arenaceous claystones and argillaceous, micaceous, sometimes oxidized, sandstones with ripples, ending with $10 \mathrm{~m}$ of thick beds of dark grey, very micaceous sandstones with some quartz druses. The San Gil Superior Formation is $620 \mathrm{~m}$ thick and is subdivided into two parts. The lower part, $230 \mathrm{~m}$ in thickness, is represented by shales, frequently interbedded by median to thick layers of sandstone and limestone. The upper part, $390 \mathrm{~m}$ in all, is composed mainly of dark shales with frequent horizons of argillaceous nodules of up to $10 \mathrm{~cm}$ in diameter, with thick to very thick layers of calcareous sandstones (ETAYO-SERnA 1968).

\section{Stratigraphy}

In order to confirm the stratigraphic extent of the San Gil Inferior and San Gil Superior formations, ammonites have been collected and studied. The oldest ammonite sampled from the San Gil Inferior Formation section is identified as ?Acanthohoplites sp. (Fig. 3L). This particular specimen displays some morphological similarities to members of the genus Acanthohoplites Sinzow, 1908. If correctly assigned, its age would be late Aptian. Higher in the section, the San Gil Superior Formation ammonite assemblage comprises four species: Lyelliceras cf. lyelli (D'ORBIGNY, 1841) (Fig. 3D-G, I, J), Prolyelliceras cf. mathewsi (Knetchel, 1947) (Fig. 3K), Glottoceras sp. (Fig. 3A, H) and Desmoceras latidorsatum (MicheLin, 1838) (Fig. 3B-C). Lyelliceras cf. lyelli is typical of the Lyelliceras lyelli Subzone which characterizes the lowest part of the 


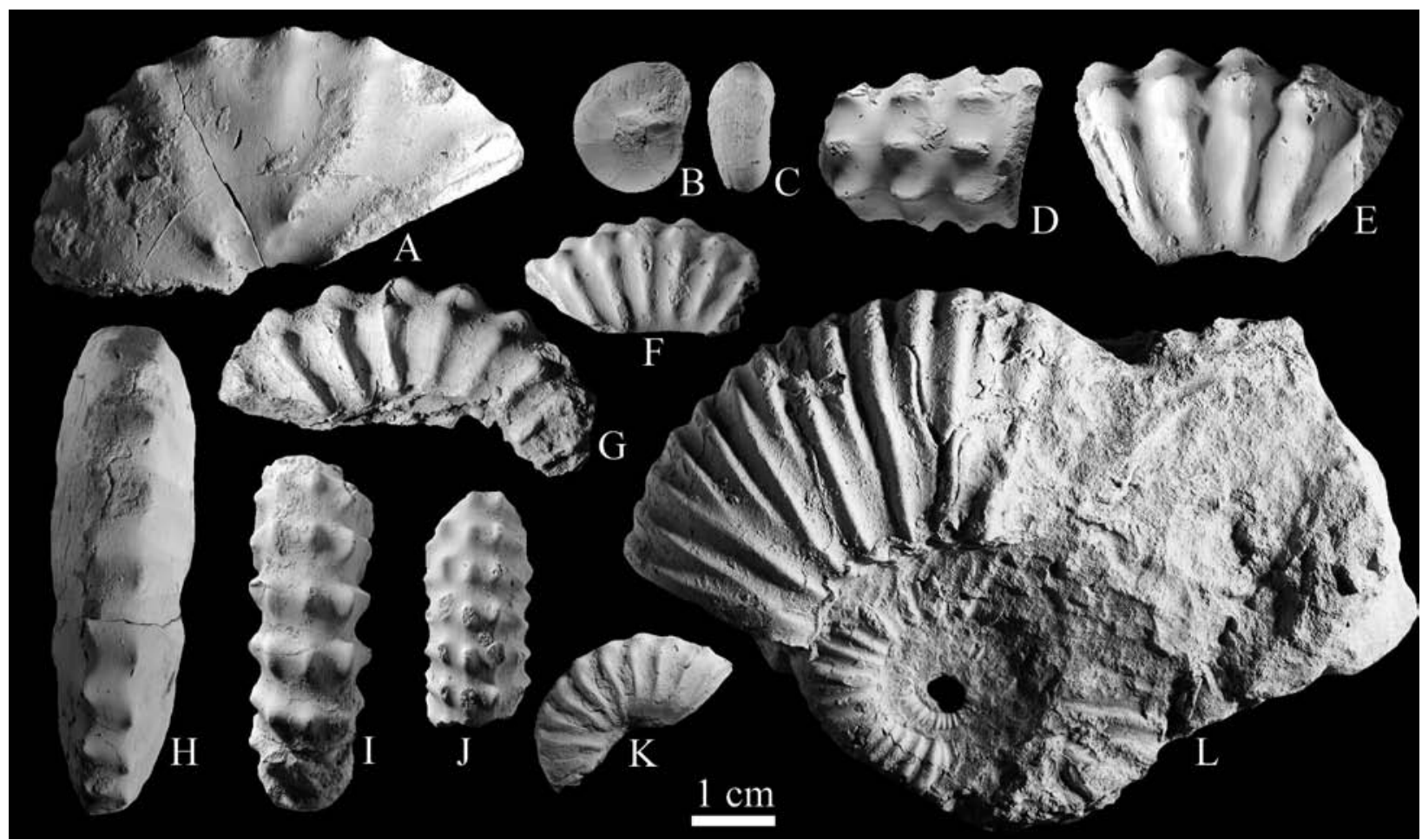

Fig. 3A, H. Glottoceras sp.; A, IGM p880655; H, IGM p880655. B, C - Desmoceras latidorsatum (Michelin, 1838), IGM p880656. D-G, I, J - Lyelliceras cf. lyelli (D’Orbigny, 1841); D, E, IGM p880657; F, IGM p880658; G, IGM p880659; I, IGM p880659; J, IGM p880658. K - Prolyelliceras cf. mathewsi (KNECHTEL, 1947), IGM p880660. L - ?Acanthohoplites sp., IGM p880661. Scale bar equals $1 \mathrm{~cm}$.

middle Albian (i.e., the lower part of the Hoplites dentatus Zone, sensu Reboulet et al. 2011) (Fig. 4).

Some problems surrounding the definition of the range of Prolyelliceras cf. mathewsi were noted by KenNedy \& KLINGER (2008). Those authors drew attention to contradictory statements in a paper by RoBERT (2002) in which the species was considered to be confined to the uppermost lower Albian (ROBERT 2002, fig. 50). However, in the same paper (ROBERT 2002, fig. 56), this species was also recorded from the lower middle Albian. The ammonite assemblage studied herein does not show signs of condensation, which is why we assume Prolyelliceras $\mathrm{cf}$. mathewsi to range from the top of the lower Albian to the base of the middle Albian. Glottoceras sp. is the Andean equivalent of the Tethys genus Knemiceras (ROBERT \& Bulot 2004), and its different species span the top of the lower to the entire middle Albian. Desmoceras latidorsatum is long ranging, first appearing in the uppermost upper Aptian and extending to the upper Cenomanian.
However, Matrion (2010) noted that the species was particularly abundant within the Lyelliceras lyelli Subzone in Aube (northeast France).

The introduction and deposition of the San Gil Superior Formation ammonite assemblage correlates with a major sea level rise, associated with the highstand of the third-order transgressive/regressive Tethys sequence Al 5 (HARDENBOL et al. 1998). The record of this highstand is significant as it coincides with the highstand of a global second-order sequence that spanned the late early to entire middle Albian. This event allows to understand the fact that the ammonite record in the San Gil Superior Formation is limited to a single level.

\section{Systematic palaeontology}

Institutional abbreviations: CAL, Colección de Paleontología de la Facultad de Ciencias, Universidad de Caldas, Manizales, Colombia; IGM, Museo Geológico Nacional 


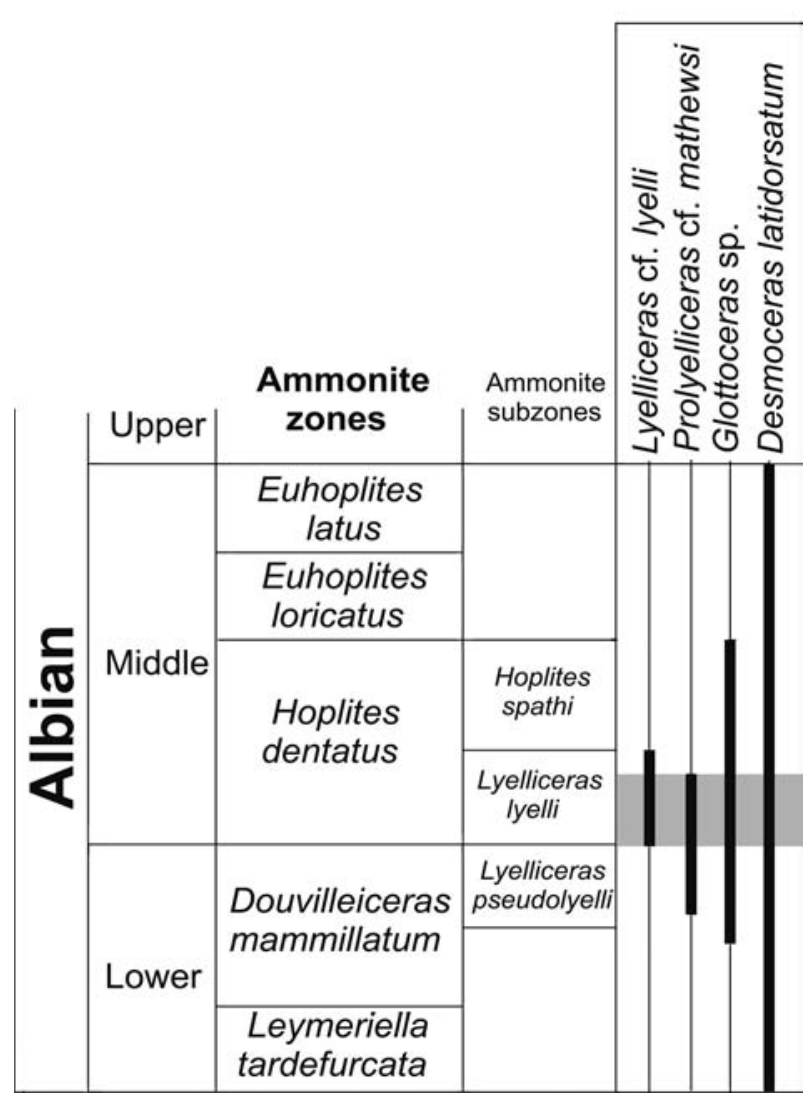

Fig. 4. Biostratigraphic range of the four ammonite species studied; the shaded area represents the age interval of the assemblage, the base of the middle Albian.

José Royo y Gómez, Servicio Geológico Colombiano, Bogotá (formerly Instituto Colombiano de Geología y Minería INGEOMINAS).

Order Decapoda Latreille, 1802 Infraorder Axiidea DE SAint Laurent, 1979

Remarks: In current literature, the higher-level classification of axiidean shrimps is not consistent. Following DE Grave et al. (2009), there are nine families, namely Axiidae Huxley, 1879; Callianassidae DanA, 1852; Callianideidae Kossmann, 1880; Calocarididae Ortmann, 1891; Ctenochelidae Manning \& Felder, 1991; Eiconaxiidae SAKAI \& Ohta, 2005; Micheleidae SAKaI, 1992; Strahlaxiidae Poore, 1994; and Thomassiniidae de Saint Laurent, 1979. In addition to these, SAKAI (2011) recognized also the family Coralaxiidae Sakai \& de Saint Laurent, 1989, which had previously been considered synonymous with Axiidae (see e.g., Poore 1994) and also erected a new family, Eiconaxi- opsididae. He also elevated many callianassid and ctenochelid subfamilies (sensu DE GRAVE et al. 2009) to family rank. The 2011 classification of SAKAI has been adopted in an outline of higher-level classification of the Crustacea by AhyOng et al. (2011).

Based on molecular data (RoBles et al. 2009), there appear to be two distinct lineages within the Axiidea, the first embracing the families Axiidae and Calocarididae (the family has currently been subsumed into Axiidae, DwOrschaK et al. 2012), the second comprising the families Callianassidae and Ctenochelidae (both sensu MANNING \& FELDER 1991), together with more basal families Strahlaxiidae, Callianideidae, Thomassiniidae (the family has been subsumed into Callianideidae, DworschaK et al. 2012), and Micheleidae. In Linnean classification, these two lineages can be grouped in superfamilies, Axioidea and Callianassoidea (e.g., Ahyong et al. 2011; SAKAI 2011), in which Axiidae and Callianassidae apparently represent most derived states within their lineages (RoBLES et al. 2009). The position of more basal families, however, is contentious (compare Poore 1994; Tudge et al. 2000; Robles et al. 2009).

The present material comprises two rather small-sized taxa which can be identified as members of the two superfamilies. In view of the fact that diagnostic features usually are not preserved in the fossil record, the placement within the families Axiidae and Callianassidae, respectively, should be regarded as preliminary. A more detailed morphological analysis of both taxa, currently under way, may provide new insight on their phylogenetic position.

\section{Family Axiidae HuXLEy, 1879}

Remarks: The present material clearly exhibits characters typical of this family, namely: 1) a compact cephalothorax, slightly shorter than the abdomen; 2) no linea thalassinica; 3) dorsolateral carinae extending to the carapace; 4) welldeveloped pleura on all abdominal somites; 5) abdominal somite 2 less than twice the length of somite 3 ; 6) abdominal pleuron 2 overlapping pleuron 1 anteriorly.

\section{Genus Paraxiopsis De Man, 1905}

\section{?Paraxiopsis sp.}

Fig. 5A-C

Description: Small-sized shrimp; carapace approximately three-quarters the length of abdomen. Dorsal carapace robust, cervical groove distinct, sinuous, located in the anterior half of the carapace, several dorsolateral carinae present (exact number unknown); linea thalassinica absent. Eyes, eye stalks, antennae or antennules unknown. Abdominal somite 1 triangular dorsally, with well-developed pointed pleura, abdominal pleuron 2 overlapping abdominal pleuron 1 anteriorly, abdominal pleura 2-6 with well-developed rounded pleurae, abdominal somites of approximately same size, except for abdominal somite 2 , less than twice as long as somite 3. Telson subquadrate, longer than wide, with two longitudinal carinae. Mouth parts unknown. Pereiopods 


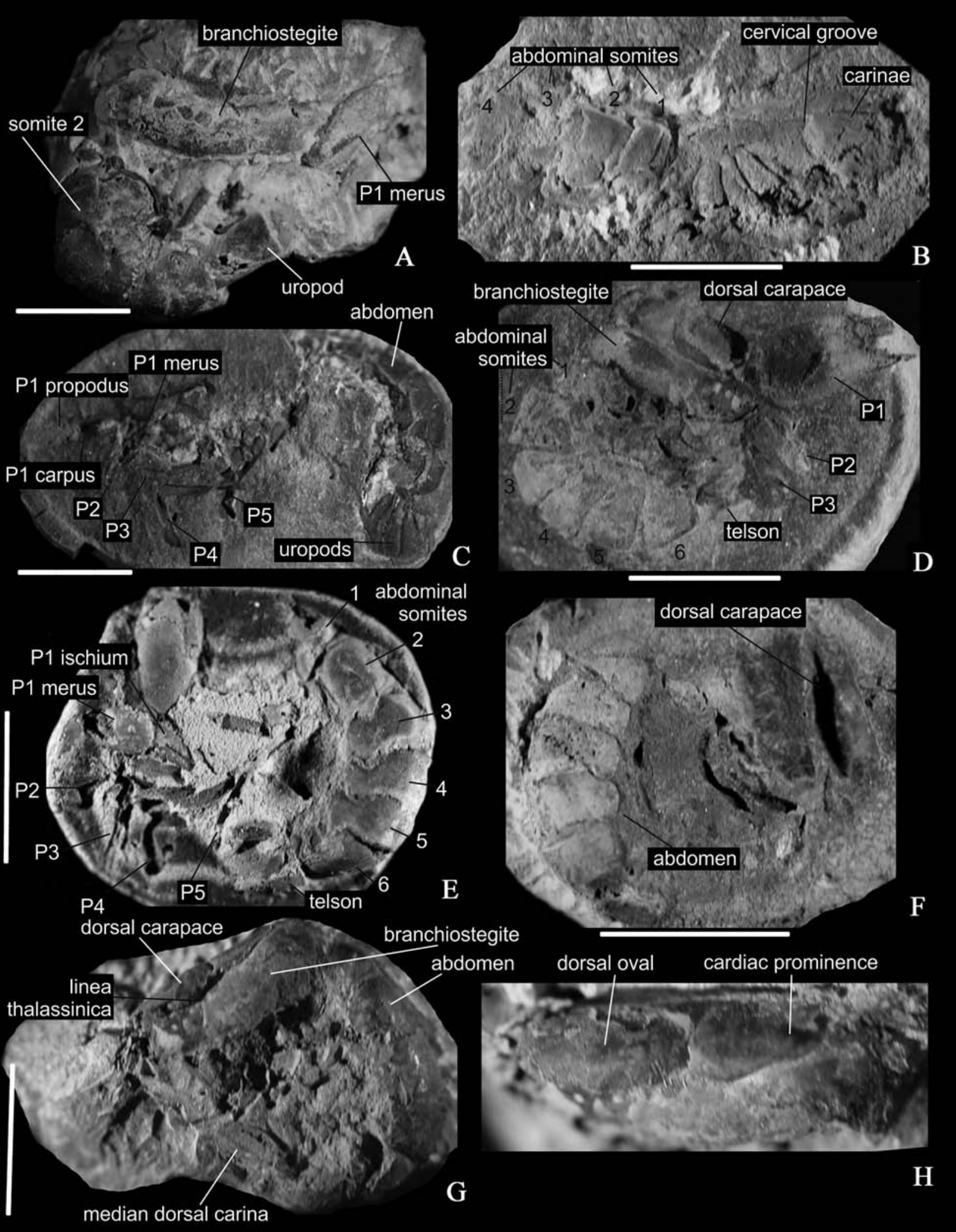

Fig. 5. 
1 chelate, only minor cheliped preserved (thus, supposed heterochely cannot be confirmed). Ischium imperfectly preserved, half the length of merus. Merus elongate, approximately four times longer than high, tapering distally, broadest at mid-length, lower margin finely serrated. Carpus longer than high, shorter than merus, triangular in outline, tapering proximally. Propodus approximately as long as carpus, imperfectly preserved. Fingers unknown. Pereiopods $2-5$ insufficiently preserved, all elements elongate and slender, most distal elements missing. Pleopods not preserved. Uropods longer than wide, ovate in outline, with median dorsal carina.

Measurements: Hypotypes IGM p880667, carapace length $38 \mathrm{~mm}$, height $8 \mathrm{~mm}$; IGM p880668, carapace length 21 $\mathrm{mm}$, height $9 \mathrm{~mm}$; IGM p880669, carapace length $36 \mathrm{~mm}$, height $7 \mathrm{~mm}$.

Occurrence: Villa de Leyva secion, Colombia; San Gil Superior Formation, middle Albian.

Remarks: The generic attribution of this material is uncertain. Although many weakly calcified details are known, it is difficult to compare them with extant taxa. Axiid genera can be distinguished from each other on the basis of the rostrum, anterior part of the carapace (presence and type of ornament) and the tail fan. The rostrum is not preserved in any of the specimens studied. Usually the position, number and ornament of carinae on the anterior part of the carapace are taxonomically important; in the present individuals, however, these are very poorly preserved, although the presence of carinae is indisputable. The tentative assignment to Paraxiopsis is based on similarities in minor cheliped shape of several extant species, namely to P. austrinus (SAKAI, 1994), P. brocki (De Man, 1888). P. defensus (Rathbun, 1901), $P$. paulayi Kensley, 2003 and $P$. pindatyba (Rodrigues \& Kensley, 1991). Kensley (2003) reviewed the differences between the Indo-Pacific species of Paraxiopsis, noting characters such as carapace setation and ornament; teeth on lateral, submedian and median carinae; shape of abdominal pleura; spination of telson and uropods, and spination, setation and ornament of articles of pereiopods 1 (chelipeds).

\section{Family Callianassidae DANA, 1852}

Remarks: The present material is best accommodated within the family Callianassidae sensu DworschaK et al. (2012). In Axiidae, Callianideidae, Micheleidae and
Strahlaxiidae, the linea thalassinica is either absent or very short (PoOre 1994; SAKai \& OHTA 2005; DworschaK et al. 2012), whereas in the specimens studied it is fully developed. This state can be seen in Callianassidae and Ctenochelidae sensu Manning \& Felder (1991) and DworschaK et al. (2012). In Thomassiniidae there is a linea thalassinica starting between the rostrum and a dorsolateral lobe next to the eye stalk (Poore 1994). For Ctenochelidae the presence of a cardiac prominence on the dorsal carapace, strongly heterochelous first pereiopods and major cheliped merus with proximal hook or blade are typical. The present material clearly possesses a cardiac prominence but chelipeds lack a meral hook. Based on material of Callianassa aquilae, described as a new species by RATHBUN (1935), the Colombian taxon was not strongly heterochelous, but rather had unequal, yet similar chelipeds with unarmed merus and with the propodus distinctly higher than the carpus. It should also be noted that cheliped characters have affinities to the thomasiniid genera Crosniera KensLey \& HeArd, 1991, Mictaxius Kensley \& Heard, 1991 and Thomassiniia DE Saint Laurent, 1979. Unlike thomassiniids, the present material has a keeled pereiopod 3 propodus, which is quite typical of callianassids. In that family the uropodal exopod has a thickened anterodorsal setose margin (PoORE 1994). It would seem that the individuals studied here lack this; however, its presence cannot be entirely ruled out due to the mode of preservation. Amongst extant callianassid taxa, the material is most closely similar to Paracalliax DE SAINT Laurent, 1979 (see below), which De Grave et al. (2009) assigned to the callianassid subfamily Paracalliacinae SAKAI, 2005.

\section{Subfamily Paracalliacinae SAKAI, 2005 Genus Rathbunassa HYŽNÝ nov.}

Type species: Rathbunassa aquilae (RATHBUn, 1935) comb. nov., monotypic.

Etymology: The generic name honours MARY J. RATHBUN, for furthering our understanding of fossil decapod crustaceans, the suffix nassa denoting affinity to the callianassid lineage.

Diagnosis: Carapace with dorsal oval and cardiac prominence; abdominal somite 1 with well-developed pleura; abdominal somite 2 longest; telson subquadrate with three longitudinal carinae; pereiopods 1 chelate, unequal in size, similar in shape; major merus ovate with lower and upper

Fig. 5. A-C - ?Paraxiopsis sp.; A, lateral view of IGM p880667; note the pleuron of abdominal somite 2 overlapping the preceding and following somites; B, lateral view of IGM p880668; note preserved carinae on carapace; anteriormost portion with rostrum is not preserved; C, lateral view of IGM p880669; P1 propodus lacking fixed finger. D-H - Rathbunassa aquilae (RATHвUN, 1935) n. comb.; D, lateral view of near-complete specimen, IGM p880670; E, lateral view of IGM p880671; note length of abdominal somite 2; F, dorsolateral view of IGM p880672; G, lateral view of IGM p880673; note median dorsal carina on uropod; G, dorsal view of cephalothorax of same specimen. Scale bars equal $1 \mathrm{~cm}$. 
margins convex, without meral hook; propodus bulbous in outline, tapering distally, upper and lower margins convex, lower margin concave at the base of fixed finger; fixed finger distinctly shorter than palm, with sharp tooth on occlusal margin positioned proximally; dactylus slender, longer than fixed finger; pereiopods 2 chelate; pereiopods 3-5 simple.

Remarks: Rathbunassa n. gen. has affinities to the extant genus Paracalliax. Both have: 1) major cheliped palm distinctly longer than fixed finger; 2) cheliped merus without meral hook and distinctly convex lower and upper margins; 3) abdominal somite 1 with well-developed pleura; 4) subquadrate telson with three longitudinal carinae. The new genus differs from Paracalliax in: 1) possession of a dactylus that is distinctly longer than the fixed finger; 2) absence of a mesial triangular depression on the cheliped carpus; 3) and more ovate shape of manus. Recently, Ossó-Morales et al. (2011) have erected a new genus, Pleuronassa, to accommodate ghost shrimps from the Upper Campanian of Morocco, which are, in some respects, comparable to Rathbunassa $\mathrm{n}$. gen. Ossó-Morales et al. (2011) noted also the resemblance between Pleuronassa and Paracalliax, mainly in cheliped morphology. Pleuronassa differs from Rathbunassa n. gen. in possessing an abdomen with subtriangular somites 3-5 with well-developed, pointed triangular pleura. In other aspects, namely general cheliped shape and features of telson and uropods, they are very close. All three genera, Paracalliax, Pleuronassa and Rathbunassa n. gen., may be closely related. Paracalliax was treated by SAKAI (2011) as a member of the family Gourretiidae SAKAI, 1999. In the diagnosis of that family, he noted the presence of a distal hook on the lower margin of the major cheliped; however, this is missing in Paracalliax. Thus, for the time being, the classification proposed by De Grave et al. (2009) is followed, and Paracalliax is interpreted as a member of the subfamily Paracalliacinae of the family Callianassidae. As such, also Rathbunassa n. gen. and Pleuronassa, as presumed relatives of Paracalliax, are treated in the same subfamily.

\section{Rathbunassa aquilae (RATHBUN, 1935) n. comb.} Fig. 5D-G

1935 Callianassa aquilae Rathbun, p. 31, pl. 7, figs. 1-5. 1996 Protocallianassa aquilae (RAthbun, 1935). - ToOLSON \& KuES, p. 114.

pars 2007 Gourretia aquilae (RATHBUN, 1935). - VEGA et al., p. 410, figs. 6.7-6.9, 6.12, non 6.10-6.11, 7.1.

2010 Gourretia aquilae (RAthbun, 1935). - SchweItZER et al., p. 41.

Diagnosis: As for genus.

Emended description: Small- to medium-sized shrimp; carapace smooth, approximately half the length of abdomen. Dorsal carapace flat and elongate with dorsal oval, cervical groove distinct, located in posterior half; linea thalassinica complete, from anterior to posterior margin, parallel on both sides of carapace; cardiac prominence in posterior part well developed. Eyes, eye stalks, antennae or antennules not recognized. Abdominal somite 1 subtriangular dorsally, with well-developed pleura; abdominal somites 2-6 subquadrate or quadrate dorsally, pleurae of abdominal somites produced into a rounded posterolateral angle, abdominal somite 2 longest, somites 4-6 of approximately same size, broader than preceding somites. Telson subquadrate, slightly longer than wide, with three longitudinal carinae. Mouth parts unknown. Pereiopods 1 chelate, unequal in size, similar in shape. Major ischium imperfectly preserved, clearly longer than high, tapering proximally with longitudinal groove laterally approximately mid-line. Merus ovate, approximately 1.5 times longer than high, lower and upper margins convex, without any apparent serration or spination. Carpus distinctly higher than long, triangular in outline. Propodus approximately twice longer than high, ovate in outline, tapering distally, distinctly higher than carpus. Upper and lower margins convex, lower margin concave at the base of fixed finger. Fixed finger distinctly shorter than palm, with sharp tooth on occlusal margin positioned proximally, tooth directed distally. Dactylus slender, slightly arched, longer than fixed finger. Both fingers with strong longitudinal carina. Minor cheliped propodus half as high as major. Pereiopods 2 chelate. Ischium and merus long and slender; carpus longer than high, triangular in outline, highest distally; propodus short, approximately as long as high; dactylus longer than fixed finger. Pereiopods 3 simple. Carpus slender, highest distally; propodus longer than carpus, lower margin with rounded proximal heel; dactylus small. Pereiopods 4 and 5 insufficiently preserved. Pleopods not preserved. Uropods longer than wide, oval in outline, approximately as long as telson, with median dorsal carina.

Measurements: Hypotypes IGM p880670, carapace length $23 \mathrm{~mm}$, height $6 \mathrm{~mm}$; IGM p880671, carapace length 29 $\mathrm{mm}$, height $5 \mathrm{~mm}$; IGM p880672, carapace length $21 \mathrm{~mm}$, height $6 \mathrm{~mm}$; IGM p880673, carapace length $22 \mathrm{~mm}$, height $6 \mathrm{~mm}$.

Occurrence: Villa de Leyva section, Colombia; San Gil Superior Formation, middle Albian; Eagle Ford Group (Turonian) of Texas and Louisiana, USA (RATHBUN 1935) and Mexico (VEga et al. 2007).

Remarks: RATHBUn (1935) first recorded Callianassa aquilae from the Turonian Eagle Ford Formation of Texas and Louisiana. Later, VEGA et al. (2007) described it from the same formation on the Mexican side of the border and reassigned it to Gourretia DE SAINT LAURENT, 1973. Re-examination of the material, however, has shown that the material described and illustrated by VEGA et al. (2007) actually consists of two taxa. Moreover, the structure interpreted by those authors as the hook on the lower margin of the major cheliped is in fact a structure protruding from beneath. It is preserved only in a single specimen (VEGA et al. 2007: fig. 7.1), which clearly is not conspecific and even not congeneric with Callianassa aquilae sensu Rathbun (1935). A formal description of this taxon awaits further examination and will follow later. 
Infraorder Brachyura LATREILLE, 1802

Section Podotremata Guinot, 1977

Subsection Raninoidia De HaAn, 1939

Superfamily Palaeocorystoidea LóRENTHEY in

LÖRENTHEY \& BEURLEN, 1929

Family Palaeocorystidae LőRENTHEY in LőRENTHEY \& Beurlen, 1929

Genus Joeranina Van Bakel, Guinot, Artal, FraAiJe \& JAGT, 2012

\section{Joeranina kerri (LuQue, FeldMANn, SCHWEITZER, JAR- MiLlo \& CAMERON, 2012)}

n. comb.

Fig. 6A-K

Additions to original description: Carapace small- to medium-sized, subhexagonally elongated, dorsal surface convex, covered by fine granules, maximum width at level of epibranchial spine; weak axial carina; orbitofrontal margin narrow, half of maximum carapace width; front narrow, bifid; frontal process clearly marked; anterolateral margins short, arched, with a single small, sharp spine plus epibranchial spine; posterolateral margins long, convex, rimmed, slightly arched at posterior fifth of carapace; posterior margin concave, rimmed, half of maximum carapace width; cervical groove well defined, relatively deep; protogastric region defined by triangular protuberance directed forwards; hepatic lobe elongated, inclined, with two small, forwardly directed protuberances; furrows mark anterior mesogastric process. Male abdomen narrow, entirely covering sternal space laterally; all somites free, somites 1,2 restricted for P5 coxae, somites 1, 2 medially raised, somite 3 with median tubercle, somites 5, 6 medially raised, somite 6 longer than preceding somites, telson small, triangular. P1 merus massive, subconical; carpus massive, subovate; P2P4 with merus, propodus, dactylus flattened; P5 reduced, subdorsal.

Measurements: Hypotypes IGM p880674, carapace width $22 \mathrm{~mm}$, length $28 \mathrm{~mm}$; IGM p880675, carapace width 12 $\mathrm{mm}$, length $18 \mathrm{~mm}$; IGM p880676, carapace width $20 \mathrm{~mm}$, length $26 \mathrm{~mm}$; IGM p880677, carapace width $8 \mathrm{~mm}$, length $14 \mathrm{~mm}$; IGM p880678, carapace width $10 \mathrm{~mm}$, length 15 $\mathrm{mm}$; IGM p880679, carapace width $30 \mathrm{~mm}$, length $31 \mathrm{~mm}$; IGM p880680, carapace width $25 \mathrm{~mm}$, length $32 \mathrm{~mm}$; IGM p880654, carapace width $32 \mathrm{~mm}$, length $35 \mathrm{~mm}$; IGM p880666, carapace width $11 \mathrm{~mm}$, length $19 \mathrm{~mm}$.

Occurrence: Villa de Leyva section, Colombia; San Gil Inferior and San Gil Superior formations, upper Aptian and middle Albian, respectively; upper Paja Formation, upper Aptian, between the village of Curití and the town of San Gil, Colombia.

Remarks: VAN BAKEL et al. (2012: 36) erected the genus Joeranina to accommodate those palaeocorystid species (previously assigned to Palaeocorystes, Eucorystes and Notopocorystes) that shared the following features “....anterior mesogastric process marked by deep, long frontal furrows, usually constricted between undefined epigastric regions; post-frontal terrace absent, only small hepatic and admedial protogastric protuberances; cervical groove complete, welldefined, also laterally, medial portion U-shaped; entire axial carina present, may be subtle to rather well-defined, raised; cuticle microstructure with granules and pits". All of these features are seen in the holotype of Notopocorystes kerri and thus we reassign it to Joeranina.

Although the holotype of Joeranina kerri n. comb. was collected from a different lithostratigraphic unit in Colombia, it is of similar age to material from the San Gil Inferior Formation, from which numerous specimens have been recovered. However, the species is also present and relatively abundant in the middle Albian (San Gil Superior Formation).

Joeranina kerri differs from congeners (see VAN BAKEL et al. 2012: 36) in having a narrower anterior margin, smaller anterolateral spine and smaller pair of tubercles on hepatic regions.

\section{Joeranina colombiana BERMÚDEZ, GÓMEZ-CRUZ \& VEGA n. sp. \\ Figs. 6L, 7A-K}

Etymology: The species name denotes the country from which the material originates.

Types (with measurements): Holotype, IGM p880681, carapace width $23 \mathrm{~mm}$, length $23 \mathrm{~mm}$; paratypes IGM p880682, carapace width $21 \mathrm{~mm}$, length $23 \mathrm{~mm}$; IGM p880683, carapace width $22 \mathrm{~mm}$, length $23 \mathrm{~mm}$; IGM p880684, carapace width $20 \mathrm{~mm}$, length $30 \mathrm{~mm}$; IGM p880685, carapace width $25 \mathrm{~mm}$, length $28 \mathrm{~mm}$; IGM p880686, carapace width 25 $\mathrm{mm}$, length $28 \mathrm{~mm}$; IGM p880687, carapace width $25 \mathrm{~mm}$, length $30 \mathrm{~mm}$; IGM p880688, carapace width $20 \mathrm{~mm}$, length $25 \mathrm{~mm}$; IGM p880689, carapace width $22 \mathrm{~mm}$, length 23 $\mathrm{mm}$; IGM p880665, carapace width $19 \mathrm{~mm}$, length $24 \mathrm{~mm}$; IGM p880664, carapace width $21 \mathrm{~mm}$, length $22 \mathrm{~mm}$.

Type locality and horizon: Villa de Leyva section, Colombia; San Gil Superior Formation, middle Abian.

Diagnosis: Carapace medium sized, subovate elongated, maximum width behind level of epibranchial spine; strong axial carina extending from tip of mesogastric process to posterior margin; anterior margin narrow, front narrow, bifid; frontal process clearly marked; anterolateral margins arched, with two sharp spines; posterior margin concave, rimmed, one-third of maximum carapace width; cervical groove weakly marked; branchiocardiac grooves close together; hepatic lobe elongated, inclined, with small protuberance directed forwards; furrows mark anterior mesogastric process. Abdomen narrow, somites 5-6 medially raised.

Description: Carapace medium sized, subovate, elongated, dorsal surface transversely convex, smooth, maximum width behind level of epibranchial spine; a strong axial carina extends from tip of mesogastric process to nearly pos- 

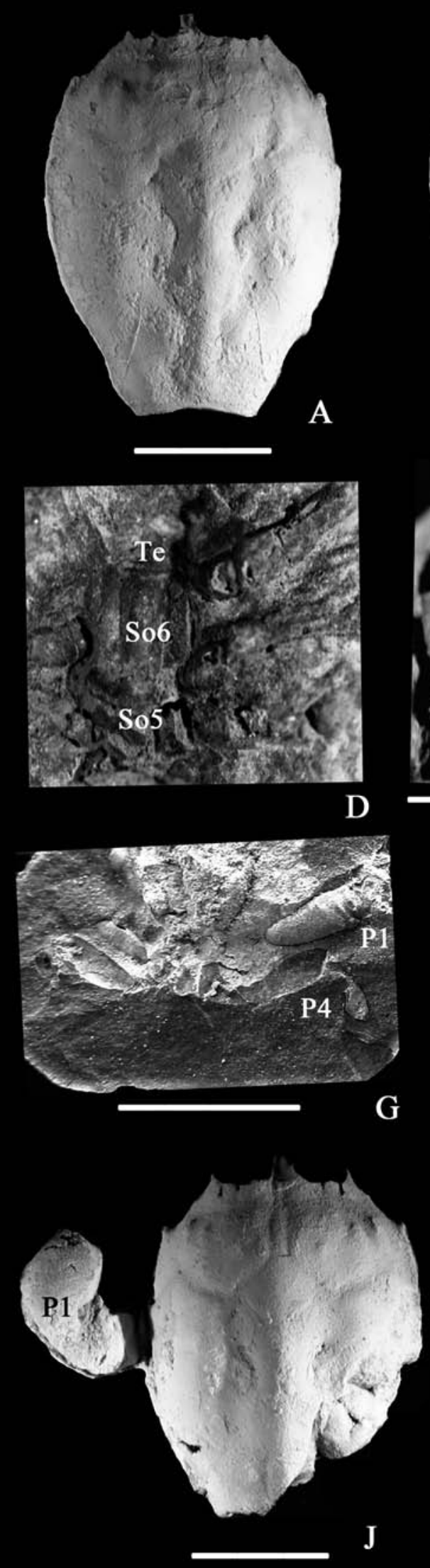
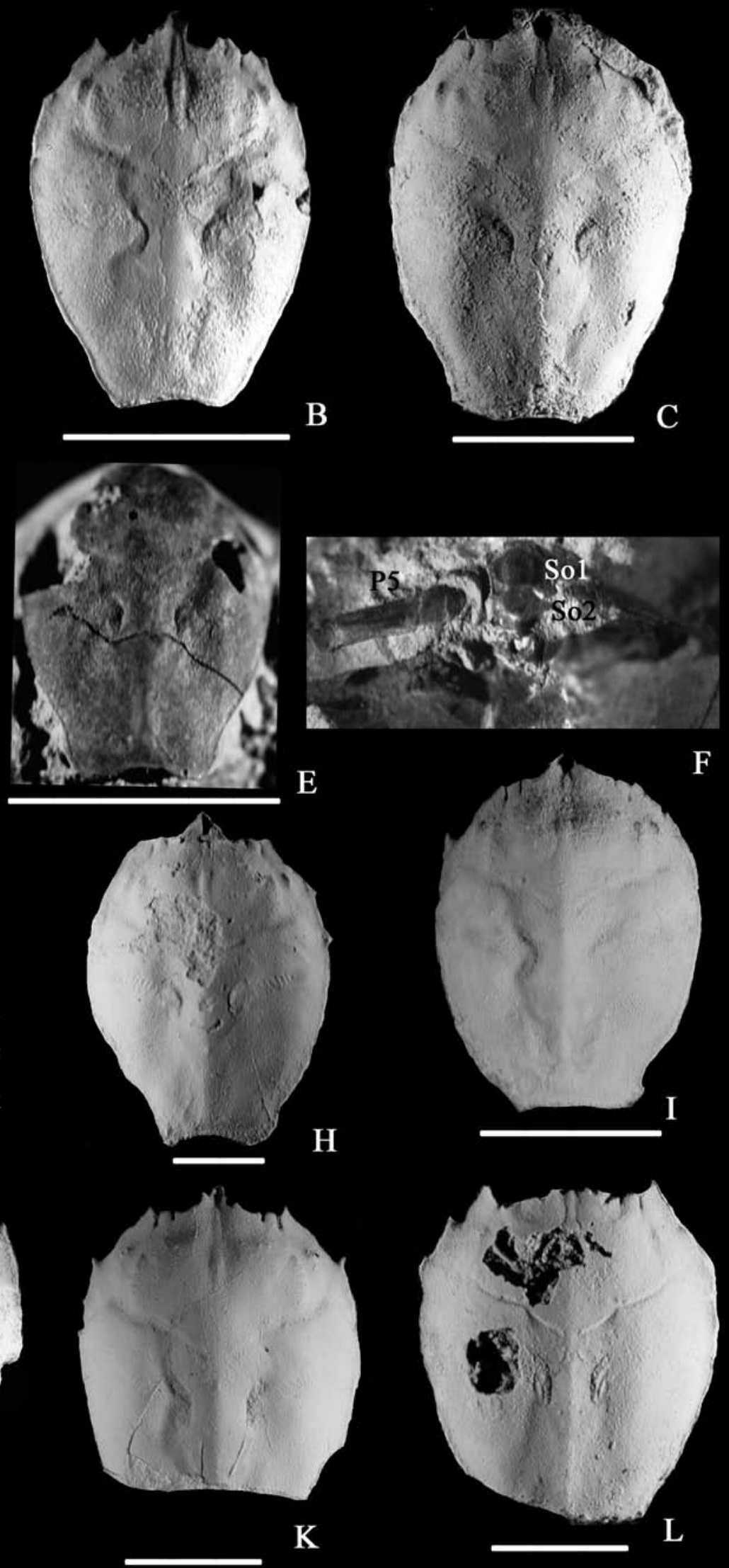

Fig. 6. 
terior margin, lateral depressions marked at both sides of carina, mainly on central portion of carapace; orbitofrontal margin narrow, two-thirds of maximum carapace width, front relatively wide for the genus, bifid; frontal process clearly marked, extending to base of front; anterolateral margins arched, with two sharp, forwardly directed spines, plus epibranchial spine; posterolateral margins convex, rimmed; posterior margin concave, rimmed, one-third of maximum carapace width; cervical groove very weak but perceptible; protogastric region defined by triangular protuberance directed forwards; hepatic lobe elongated, inclined, with small, forwardly directed protuberance; furrows mark anterior mesogastric process. Male abdomen narrow, entirely covering sternal space laterally; all somites free, somites 5-6 medially raised, somite 6 longer than preceding somites.

Remarks: The new species differs from congeners mainly by possessing a relatively wide, subovate carapace shape. Joeranina broderipii (MANTELL, 1844) (Albian, England and France) has a wider orbitofrontal margin and larger anterolateral spines; J. gaspari VAN BAKEL, GUINOT, ARTAL, FraAiJE \& JAGT, 2012 (Albian, Spain) has a wider anterior margin with a larger pair of anterolateral spines and a larger outer orbital spine; J. harveyi (WoodwARD, 1896) (Upper Cretaceous, Canada) possesses three, larger anterolateral spines, a more elongate carapace and a wider orbitofrontal margin; J. japonica (JiMBÔ, 1894) (Upper Cretaceous, Japan; see also Matsumoto 1963; Collins et al. 1993) has a wider orbitofrontal margin, a near-elongate trapezoidal carapace and a longer anterolateral spine. Joeranina kerri has a more slender carapace, slightly narrower orbitofrontal margin, a pair of tubercles on the hepatic regions, only a single anterolateral spine and a more clearly developed cervical groove; J. paututensis (COLLINS \& WIENBERG RASMUSSEN, 1992) (Upper Cretaceous, Greenland) has a more elongated carapace with stronger anterolateral and frontal spines, while J. platys (SchweItzer \& Feldmann, 2001) (see Fig. 8A-C; Albian, Oregon, USA and Upper Cretaceous, Canada; compare SchweITZER et al. 2003, 2009) is closest to $J$. colombiana n. sp. in carapace outline and in having a strong dorsal carina, but differs in possessing a slightly wider orbitofrontal margin, only one anterolateral spine and in showing clearly developed branchiocardiac grooves. Joeranina syriaca (WITHERs, 1928) (Upper Cretaceous, Syria) is based on an incomplete carapace. However, a strong dorsal carina can be seen, in addition to a pair of tubercles on the hepatic region and a marked epibranchial spine, which sets it apart from the new Colombian species.

\section{Family Cenomanocarcinidae GuInOt, VeGa \& VAN BAKEL, 2008 \\ Genus Cenomanocarcinus VAN STRaelen, 1936}

Cenomanocarcinus vanstraeleni STENZEL, 1945 Fig. 8D-F

1945 Cenomanocarcinus vanstraeleni STENZEL, p. 447, text-fig. 15

1968 Cenomanocarcinus vanstraeleni. - FöRSTER, fig. 4.

1980 Necrocarcinus vanstraeleni (STENZEL, 1945). Kues, p. 862, text-fig. 1.

1989 Cenomanocarcinus vanstraeleni. - Finsley, p. 98, pl. 78, figs. 307-308.

1992 Cenomanocarcinus vanstraeleni. - BisHop et al., fig. $7 \mathrm{c}$.

? 1996 Necrocarcinus (Cenomanocarcinus) vanstraeleni (STEnZel, 1945). - Toolson \& Kues, p. 114, fig. 1.5.

1999 Ophthalmoplax spinosus Feldmann, Villamil \& Kauffman, p. 96, figs. 3.1, 3.2, 4.1, 4.2.

2007 Cenomanocarcinus vanstraeleni. - VEGA et al., p. 412, figs. 7.2-7.9, 8.1-8.11, 9.1-9.5.

2007 Cenomanocarcinus vanstraeleni. - PATARRoYO \& ROJAS-BRICEÑo, p. 92, pl. 2, figs. 1-4.

2008 Cenomanocarcinus vanstraeleni. - Guinot et al., p. 11, figs. 2, 3A-D, 3F, 4, 5.

2008 Cenomanocarcinus sp. - Guinot et al., p. 694, fig. $3 \mathrm{E}$.

2010 Cenomanocarcinus vanstraeleni. - VEGA et al., p. 269, figs. 7, 8.1-8.5.

2012 Cenomanocarcinus vanstraeleni. - VAN BAKEL et al., p. 56, fig. 18B-C, E.

Measurements: Hypotype IGM p880690, carapace width $53 \mathrm{~mm}$, length $38 \mathrm{~mm}$.

Occurrence: Villa de Leyva section, Colombia; San Gil Superior Formation, middle Abian.

Remarks: GuiNOT et al. (2008) illustrated the sternum of a specimen, referred to as Cenomanocarcinus sp., from the

Fig. 6. A-K - Joeranina kerri (Luque, Feldmann, Schweitzer, Jaramillo \& Cameron, 2012) n. comb., all specimens from the San Gil Superior Formation, middle Albian; A, dorsal view of IGM p880674; B, dorsal view of IGM p880675; C, dorsal view of IGM p880676; D, ventral view of same specimen; note abdominal somites 5, 6 and telson (So5, So6, Te); E, dorsal view of IGM p880677; F, posterior view of same specimen; note abdominal somites 1, 2 and fifth pereiopod (So1, So2, P5); G, dorsal view of IGM p880678 (internal mould), note first and fourth pereiopods (P1, P4); H, dorsal view of IGM p880654; I, dorsal view of IGM p880666; J, dorsal view of IGM p880680; K, dorsal view of IGM p880679. L. Joeranina colombiana n. sp., dorsal view of IGM p880683 (paratype), from the San Gil Superior Formation, middle Albian. Scale bars equal $1 \mathrm{~cm}$. 


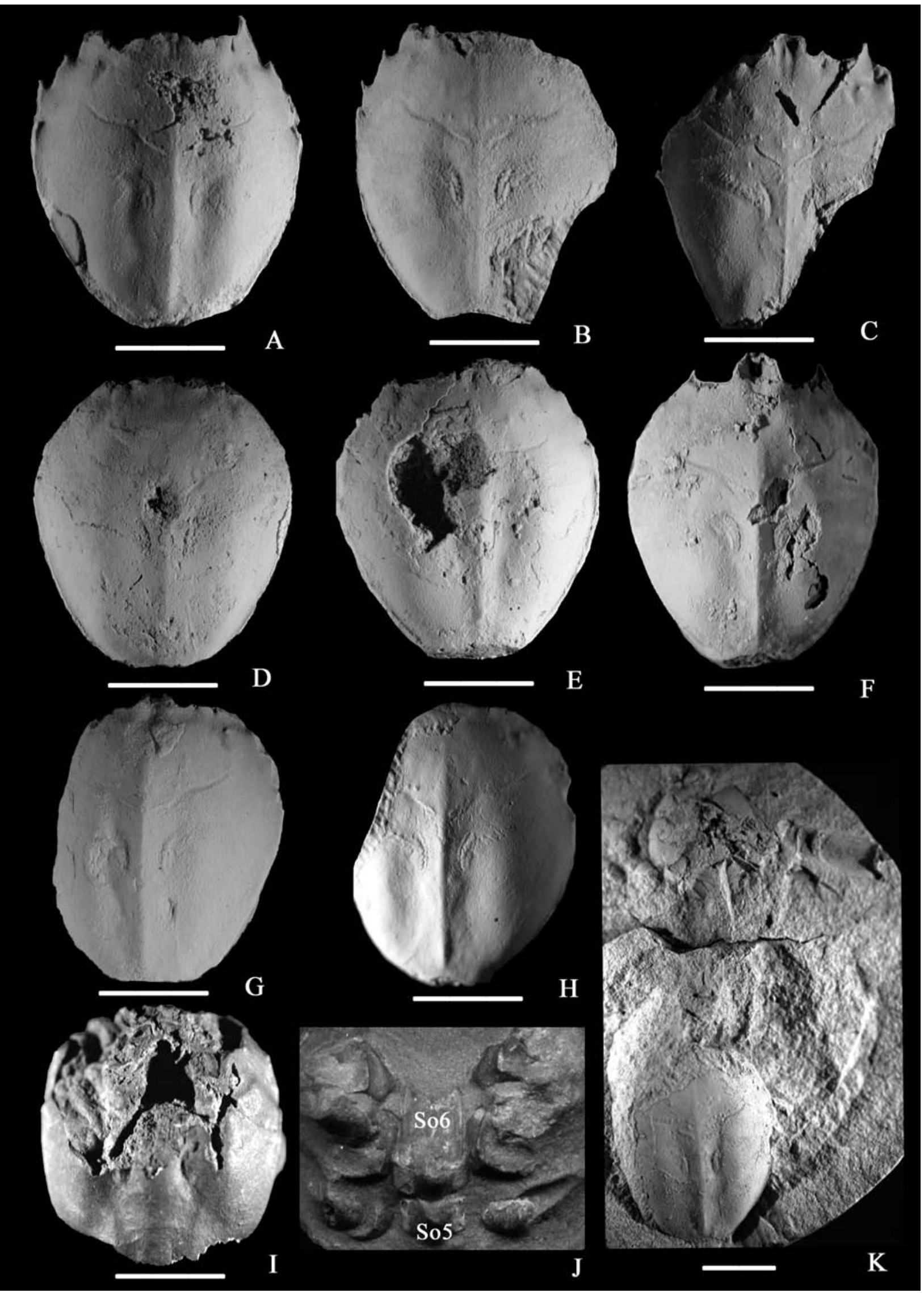

Fig. 7. 
San Gil Superior Formation, then considered to be of late Albian date. The same specimen (see also Fig. 8D, E) was subsequently illustrated and redescribed as Cenomanocarcinus vanstraeleni by VeGA et al. (2010). A second carapace is recorded here, from the same locality. Based on biostratigraphic data discussed above, the range for this species is here extended to the middle Albian. A related species of Albian age is $C$. cantabricus Van Bakel, Guinot, Artal, FraAiJe \& JAGT, 2012, from Cantabria, Spain. The two specimens of $C$. cantabricus seem to differ from $C$. vanstraele$n i$ from the middle Albian of Colombia in carapace shape (more ovate in the Colombian specimens), as well as in the number and strength of spines on the anterolateral margins and of tubercles on branchial crests.

Family Necrocarcinidae Förster, 1968

Genus Planocarcinus LuQue, Feldmann, Schweitzer, JARAMILLO \& CAMERON, 2012

\section{Planocarcinus johnjagti Bermúdez, GómEz-CRUZ \& VEGA n. sp.}

Fig. $8 \mathrm{H}-\mathrm{K}$

Etymology: The species name honours JoHN W.M. JAGT, a prominent palaeontologist and stratigrapher, whose contributions to the knowledge and evolution of fossil decapod crustaceans are notable.

Types (with measurements): Holotype CAL06837b, carapace width $18 \mathrm{~mm}$, length $19 \mathrm{~mm}$; paratype CAL06833b, carapace width $21 \mathrm{~mm}$, length $17 \mathrm{~mm}$.

Type locality and horizon: Villa de Leyva section, Colombia; San Gil Inferior Formation, upper Aptian.

Diagnosis: Carapace subhexagonal, nearly as long as wide; orbitofrontal margin half of total carapace width; anterolateral margin with four small spines; posterolateral margin arched; posterior margin concave; dorsal regions poorly defined, protogastric lobes with transverse row of four small tubercles; cervical groove incompletely defined. Chelipeds unequal, right cheliped more massive. Thoracic sternum narrow; sternite 3 coronate; sternite 4 subtrapezoidal elongated, episternite 4 suboval; sternite 5 subsquare, episternite 5 extended posterolaterally. Abdomen of indeterminate sex narrow, somite 1 subcylindrical, somites 2 and 3 similar in size and shape to somite 1 .

Description: Carapace subhexagonal, nearly as long as wide, widest at mid-length; orbitofrontal margin half of total carapace width, orbits large, two fissures in upper orbital margins, outer orbital spine short; anterolateral margin with four small spines; posterolateral margin twice the length of anterolateral margin, arched; posterior margin concave, rimmed, half of maximum carapace width; dorsal regions poorly defined, surface finely granular, protogastric lobes with transverse row of four small tubercles; cervical groove incompletely defined; branchiocardiac grooves arched. Chelipeds unequal, right cheliped more massive than left, meri of both chelipeds subconical, carpus of left cheliped subtriangularly inverted. Other pereiopods incomplete or not preserved. Thoracic sternum narrow, slightly wider posteriorly, sternites 1, 2 not seen; sternite 3 coronate; sternite 4 subtrapezoidal elongated, episternite 4 suboval, extending laterally; sternite 5 subsquare, episternite 5 also extended posterolaterally, slightly longer than episternite 4. Abdomen of indeterminate sex narrow, somite 1 subcylindrical, tightly fitted between P5 coxae, somites 2 and 3 similar in size and shape to somite 1.

Remarks: The new species differs from Planocarcinus olssoni (Rathbun, 1937) from the upper Aptian Paja Formation (Fig. 8G) in carapace shape, being not as rounded, a narrower rostrum and deeper orbital fissure. The branchial area is not as expanded in the new species and its posterior margin is more concave and rimmed.

VeGA et al. (2010) made a mistake placing the specimen of $P$. olssoni as Orithopsis tricarinata (BELL, 1863). LuQue et al. (2012) correctly assigned it to the Necrocarcinidae; sternum shape appears to confirm this attribution. The sternum of specimen LP06837b is similar to that of Necrocarcinus labeschei (Eudes-DeslongChamps, 1835) (see Karasawa et al. 2011: fig. 10B-C; Schweitzer et al. 2012: fig. 2B-C). The dorsal carapace of Planocarcinus bears similarities to the subfamily Paranecrocarcininae FraAIJE, VAN BAKEL, JAGT \& ARTAL, 2011, such as the subhexagonal carapace shape, the front projecting beyond the orbits, and the possession of postorbital slits (barely visible in the anterior portion of carapace in fig. 3A of LuQuE et al. 2012). However, better-preserved specimens are needed to confirm placement in that subfamily. San Gil Inferior specimen LP06837b also resembles the palaeocorystid Cenocorystes bretoni Van Bakel, Guinot, Artal, FraAiJe \& Jagt, 2012,

Fig. 7. A-K - Joeranina colombiana n. sp., all specimens from the San Gil Superior Formation, middle Albian; A, dorsal view of IGM p880681 (holotype); B, dorsal view of IGM p880682; C, dorsal view of IGM p880684; D, dorsal view of IGM p880685; E, dorsal view of IGM p880686; F, dorsal view of IGM p880687; G, dorsal view of IGM p880665; H, dorsal view of IGM p880664; I, dorsal view of IGM p880689; J, ventral view of same specimen; note abdominal somites 5, 6 (So5, So6); K, dorsal view of IGM p880688; note specimen of Rathbunassa aquilae (RATHBun, 1935) n. comb. on top. Scale bars equal $1 \mathrm{~cm}$. 

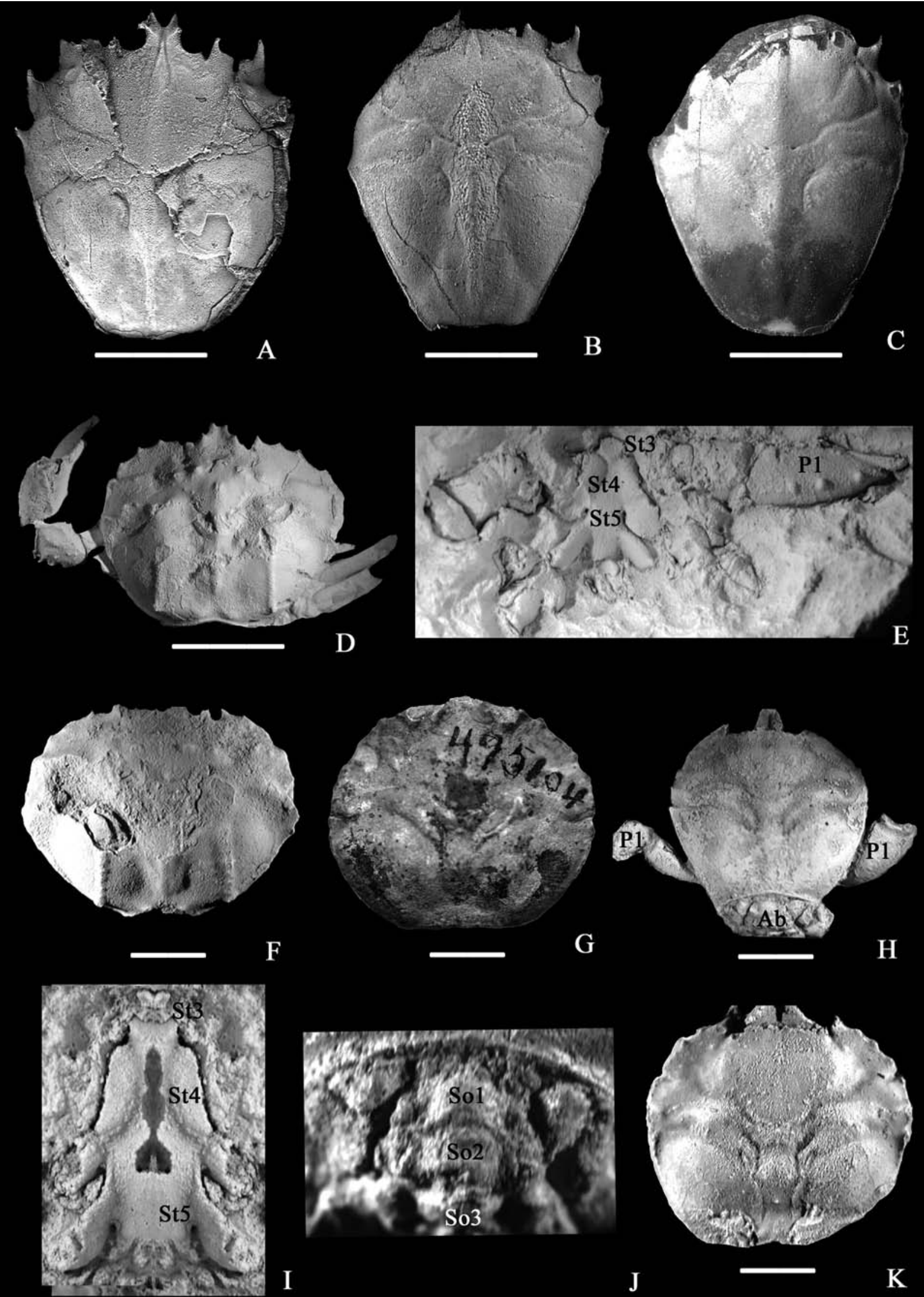

Fig. 8. 
in having a subhexagonal carapace, with four anterolateral spines and similar cervical, postcervical and banchiocardiac grooves; however, the shape of the sternum illustrated in VAN BAKEL et al. (2012: fig. 2C) differs from that of specimen LP06837b.

\section{Conclusions}

The Villa de Leyva locality probably represents the richest locality in Colombia with respect to decapod crustacean fossils. Associated ammonites have enabled a refinement of the age assignment of the San Gil Inferior and San Gil Superior formations. To date, nine species are on record from Colombia, namely ?Paraxiopsis sp., Rathbunassa aquilae n. comb., Meyeria magna M'Coy, 1849, Joeranina kerri, J. colombiana n. sp., Cenomanocarcinus vanstraeleni, Planocarcinus olssoni, Planocarcinus johnjagti n. sp., and Ophthalmoplax triambonatus Feldmann \& VilLamil, 2002. The total number of specimens for each species is representative of their relative abundance within local decapods crustacean assemblages, J. kerri being the most abundant. It is interesting to note that two species from this assemblage, i.e., Rathbunassa aquilae and Cenomanocarcinus vanstraeleni, are also known from Cenomanian-Turonian strata exposed at quarries near Múzquiz, northeast Mexico. Cenomanocarcinus vanstraeleni also occurs in the Turonian San Rafael Formation in the department of Boyacá, Colombia (VEGA et al. 2007, 2010).

\section{Acknowledgements}

Earlier suggestions supplied by BARRY W.M. VAN BAKEL (Oertijdmuseum De Groene Poort, Boxtel, the Netherlands) and Hiroaki Karasawa (Mizunami Fossil Museum, Japan) are highly appreciated. Special thanks to JoHN W. M. JAGT (Natuurhistorisch Museum Maastricht, de Bosquetplein, Maastricht, the Netherlands), BARRY W.M. VAN BAKEL and Torrey Nyborg (Loma Linda University, California, USA) for review and criticism to the original manuscript. We thank Rick Ross (Oregon, USA) and Àlex Ossó-Morales (Tarragona, Catalonia) for their kind loan of comparative material. Torrey Nyborg helped with images of some specimens. JEAN-LouIs LATIL (Lazer, France) and BERTRAND MAtrion (Buchères, France) supplied comments on the ammonites collected and shared important references. Instrumental in discovering and collecting numerous specimens from Albian strata were LiLiAnA Bolivar and DANIELA BERMUDEz (Bogotá Colombia), who participated in various field trips to the area. José Arenas (Museo Geológico José Royo y Gómez, Servicio Geológico Colombiano, Colombia) helped with temporary export permits.

\section{References}

Ahyong, S.T., Lowry, J.K., Alonso, M., Bamber, R.N., Boxshall, G.A., Castro, P., Gerken, S., Karaman, G.S., Goy, J.W., Jones, D.S. Meland, K., Rogers, D.C. \& Svavarsson, J. (2011): Subphylum Crustacea Brünnich, 1772. - In: ZHANG, Z.-Q. (Ed.): Animal biodiversity: an outline of higher-level classification and survey of taxonomic richness. - Zootaxa, 3148: 165-191.

BeLL, T. (1863): A monograph of the fossil malacostracous Crustacea of Great Britain, Pt. II, Crustacea of the Gault and Greensand. - Monographs of the Palaeontographical Society London, 1863: 1-40.

Bishop, G.A., Brannen, N.A., Hill, L.E., Meyer, J.P., Pike, A.J. \& SAmpson, C. (1992): The Britton Notopocorystes assemblage: an Eagle Ford decapod assemblage from the Cretaceous of North-Central Texas. - Transactions of the 42nd Annual Convention: Jackson, Massachusetts, USA, 413-424; Jackson (Gulf Coast Association of Geological Societies).

Collins, J.S.H., Kanie, Y. \& Karasawa, H. (1993): Late Cretaceous crabs from Japan. - Transactions and Proceedings of the Palaeontological Society of Japan, new series, 172: 292-310.

Collins, J.S.H. \& Wienberg Rasmussen, H. (1992): Upper Cretaceous-Lower Tertiary decapod crustaceans from West Greenland. - Bulletin fra Grønlands geologiske Undersøgelse, 162: 1-46.

DANA, J.D. (1852): Conspectus crustaceorum quae in orbis terrarum circumnavigatione, Carol Wilkes e classe reipublicae foederatae duce, lexit e descripsit. - Proceed-

Fig. 8. A-C - Joeranina platys (Schweitzer \& Feldmann, 2001), dorsal view of carapaces, all specimens from the Santonian-Campanian Haslam Formation, British Columbia, Canada (private collections). D-F - Cenomanocarcinus vanstraeleni STEnZEL, 1945, specimens from the upper San Gil Superior Formation, middle Albian; D, dorsal view of hypotype INGEOMINAS-JCR-1; E, ventral view of same specimen; note sternites 3 to 5 (St3-St5) and merus of first pereiopod (P1); F, dorsal view of hypotype IGM p880690. G - Planocarcinus olssoni (RATHBUn, 1937), dorsal view of holotype USNM 495104, upper Paja Formation, upper Aptian. H-K - Planocarcinus johnjagti n. sp., specimens from the San Gil Inferior Formation, upper Aptian; H, dorsal view of holotype CAL06837b; note unequal left and right first pereiopods as well as abdomen (P1, Ab); I, composite image of sternum of same specimen; note sternites 3 to 5 (St3-St5); J, posterior view of same specimen; note abdomen with abdominal somites 1 to 3 (So1-So3); K, dorsal view of paratype CAL06833b. Scale bars equal $1 \mathrm{~cm}$. 
ings of the Academy of Natural Sciences of Philadelphia, 6: 6-28.

De Grave, S., Pentcheff, N.D., Ahyong, S.T., Chan, T.Y., Crandall, K.A., DworschaK, P.C., Felder, D.L., Feldmann, R.M., Fransen, C.H.J.M., Goulding, L.Y.D., Lemaitre, R., Low, M.E.Y., Martin, J.W., NG, P.K.L., Schweitzer, C.E., TAn, S.H., Tshudy, D. \& Wetzer, R. (2009): A classification of living and fossil genera of decapod crustaceans. - The Raffles Bulletins of Zoology, Supplements, 21: 1-109.

De HaAn, W. (1833-1850): Crustacea. - In: Siebold, P.F. v. (Ed.): Fauna Japonica sive Descriptio Animalium, quae in Itinere per Japoniam, Jussu et Auspiciis Superiorum, qui summum in India Batava Imperium Tenent, Suscepto, Annis 1823-1830 Collegit, Notis, Observationibus et Adumbrationibus Illustravit: i-xvii, i-xxxi, ix-xvi, 1-243, pls. A-J, L-Q, 1-55, circ. table 2; Lugduni Batavorum (J. Müller et Co.).

De Man, J.G. (1888): Bericht über die von Herrn Dr. J. Brock im indischen Archipel gesammelten Decapoden und Stomatopoden. - Archiv für Naturgeschichte, 53: 289-600.

DeMan, J.G. (1905): Diagnoses of new species of macrurous decapod Crustacea from the "Siboga-Expedition". - Tijdschrift der Nederlandsche Dierkundige Vereeniging, 9: 587-614.

Dworschak, P.C., Felder, D.L. \& Tudge, C.C. (2012): Infraorders Axiidea DE SAInt LAurent, 1979 and Gebiidea DE SAInT LAURENT, 1979 (formerly known collectively as Thalassinidea). - In: Schram, F.R., Vaupel Klein, J.C. von, Charmantier-Daures, M. \& Forest, J. (Eds.): Treatise on Zoology - Anatomy, Taxonomy, Biology The Crustacea, Decapoda, Volume 9 Part B Decapoda: Astacidea P.P. (Enoplometopoidea, Nephropoidea), Glypheidea, Axiidea, Gebiidea, and Anomura, 9B: 109219.

Etayo-Serna, F. (1968): El sistema Cretáceo en la región de Villa de Leyva y zonas próximas. - Geología Colombiana, 5: 5-74.

Eudes-Deslongchamps, J.A. (1835): Mémoire pour servir à l'histoire naturelle des Crustacés fossiles. - Mémoires de la Societé Linnéenne de Normandie, 5: 37-46.

Feldmann, R.M. \& Villamil, T. (2002): A new carcineretid crab (upper Turonian, Cretaceous) of Colombia. - Journal of Paleontology, 76: 718-724.

Feldmann, R.M., Villamil, T. \& Kauffman, E.G. (1999): Decapod and stomatopod crustaceans from mass mortality Lagerstätten: Turonian (Cretaceous) of Colombia. - Journal of Paleontology, 73: 91-101.

Finsley, C. (1989): A Field Guide to Fossils of Texas. - 188 pp.; Austin (Texas Monthly Press).

FÖRSTER, R. (1968): Paranecrocarcinus libanoticus n. sp. (Decapoda) und die Entwicklung der Calappidae in der Kreide. - Mitteilungen der Bayerischen Staatssammlung für Paläontologie und historische Geologie, 8: 167195.

FraaiJe, R.H.B., Van Bakel, B.W.M., Jagt, J.W.M. \& ARTAL, P. (2008): New decapod crustaceans (Anomura, Brachyura) from mid-Cretaceous reefal deposits at Monte Orobe (Navarra, northern Spain), and comments on related type-Maastrichtian material. - In: STEURBAUT,
E., JaGt, J.W.M. \& Jagt-Yazykova, E.A. (Eds.): Annie V. Dhondt Memorial Volume. - Bulletins de l'Institut royal des Sciences naturelles de Belgique, Sciences de la Terre, 78: 193-208.

Guinot, D. (1977): Propositions pour une nouvelle classification des Crustacés Décapodes Brachyoures. - Comptes Rendus hebdomadaires des Séances de l'Académie des Sciences, D285: 1049-1052.

Guinot, D., Vega, F.J. \& VAn BaKel, B.W.M. (2008): Cenomanocarcinidae n. fam., a new Cretaceous podotreme family (Crustacea, Decapoda, Brachyura, Raninoidea), with comments on related families. - Geodiversitas, 30: 681-719.

Hardenbol, J., Thierry, J., Farley, M.B., Jacquin, T., DE Graciansky, P.C. \& VAIL, P.R. (1998): Mesozoic and Cenozoic sequence chronostratigraphic framework of European basins. - In: De Graciansky, P.C., HardenBol, J., Jacquin, T. \& VAIL, P.R. (Eds.): Mesozoic and Cenozoic sequence stratigraphy of European basins. SEPM Special Publications, 60: 3-14.

HuXley, T.H. (1879): On the classification and the distribution of the crayfishes. - Proceedings of the Zoological Society of London, 1878: 752-788.

Jimbô, K. (1894): Beiträge zur Kenntniss der Fauna der Kreideformation von Hokkaidô. - Palaeontologische Abhandlungen, neue Folge, 2: 149-194.

Karasawa, H., Schweitzer, C.E. \& Feldmann, R.M. (2011): Phylogenetic analysis and revised classification of podotrematous Brachyura (Decapoda) including extinct and extant families. - Journal of Crustacean Biology, 31: $523-565$.

Kennedy, W.J. \& Klinger, H.C. (2008): Cretaceous faunas from Zululand and Natal, South Africa. The ammonite subfamily Lyelliceratinae Spath, 1921. - African Natural History, 4: 57-111.

Kensley, B. (2003): Axioid shrimps from Guam (Crustacea, Decapoda, Thalassinidea). - Micronesica, 35-36: 359384.

Kensley, B. \& Heard, R.W. (1991): An examination of the shrimp family Callianideidae (Crustacea: Decapoda: Thalassinidea). - Proceedings of the Biological Society of Washington, 104: 493-537.

Knechtel, M.M. (1947): Albian ammonite faunas from Peru. - In: Knechtel, M.M., Richards, E.F. \& RathBUn, M.J. (Eds.): Mesozoic fossils of the Peruvian Andes. - Johns Hopkins University Studies in Geology, 1: $1-150$

Kossmann, R. (1880): Malacostraca, (2. Theil: Anomura). - In: Kossmann, R. (Ed.): Zoologische Ergebnisse einer im Auftrage der Königlichen Academie der Wissenschaften zu Berlin ausgeführten Reise in die Küstengebiete des Roten Meeres, 2: 67-140; Leipzig (Engelmann).

Kues, B.S. (1980): A fossil crab from the Mancos Shale (Upper Cretaceous) of New Mexico. - Journal of Paleontology, 54: 862-864.

LATreille, P.A. (1802-1803): Histoire naturelle, générale et particulière, des Crustacés et des Insectes, 3: 1-468; Paris (Dufart).

Lôrenthey, E. \& Beurlen, K. (1929): Die fossilen Decapoden der Länder der Ungarischen Krone. - Geologica Hungarica, Series Palaeontologica, 3: 1-421. 
Luque, J., Feldmann, R.M., Schweitzer, C.E., JaramilLo, C. \& CAmeron, C.B. (2012): The oldest frog crabs (Decapoda: Brachyura: Raninoida) from the Aptian of northern South America. - Journal of Crustacean Biology, 32: 405-420.

Manning, R.B. \& Felder, D.L. (1991): Revision of the American Callianassidae (Crustacea: Decapoda: Thalassinidea). - Proceedings of the Biological Society of Washington, 104: 764-792.

Mantell, G.A. (1844): The Medals of Creation; first lessons in Geology, and in the Study of Organic Remains, 2: 457-1016; London (Bohn).

Matrion, B. (2010): Ammonites. - In: Colleté, C. (Ed.): Le stratotype de l'Albien. - Patrimoine géologique, 2: 99193; Paris (Muséum national d'Histoire naturelle).

Matsumoto, T. (1963): A survey of the fossils from Japan illustrated in classical monographs. Part 10. KотоRA JiMBо (1894). Beiträge zur Kenntniss der Fauna der Kreideformation von Hokkaido. - Palaeontological Society of Japan, 25th Anniversary Volume: 41-48.

M'Coy, F. (1849): On the classification of some British fossil Crustacea with notices of new forms in the University Collection at Cambridge. - Annals and Magazine of Natural History, series 2, 4: 161-179.

Michelin, H. (1838): Note sur une argile dépendant du Gault, observée au Gaty, commune de Gérodot, départment de l'Aube. - Mémoires de la Société géologique de France, 1 (3): 97-103.

Orbigny, A.D. DE (1841): Paléontologie française. Description zoologique et géologique de tous les animaux mollusqes et rayonnés fossiles de France. Terrains Crétacés. 1, Céphalopodes. Part II (1841), 121-430; Paris (Masson).

Ortmann, A.E. (1891): Die Decapoden-Krebse des Strassburger Museums mit besonderer Berücksichtigung der von Herrn Dr. Döderlein bei Japan und bei den Liu-KiuInseln gesammelten und zur Zeit im Strassburger Museum aufbewahrten Formen. III. Theil. Die Abtheilungen der Reptantia Boas: Homaridea, Loricata und Thalassinidea. - Zoologische Jahrbücher, Abteilung für Systematik, Geographie und Biologie der Thiere, 6: 1-58.

Ossó-Morales, À., Garassino, A., Vega, F.J. \& Artal, P. (2011): Pleuronassa timerchidouensis n. gen., n. sp. (Axiidea, Callianassidae) from the Calcaires à slumps de Taghit Fm., Late Campanian of the Moyenne Moulouya, NE Morocco. - Atti della Società italiana di Scienzi Naturali e del Museo Civico di Storia naturale in Milano, 152 (2): 161-171.

Patarroyo, P. \& Rojas-Briceño, A. (2007): La sucesión y la fauna del Turoniano de la Formación San Rafael en Pesca y su comparación con la sección tipo en Samacá (Boyacá-Colombia-S.A.). - Geología Colombiana, 32: 89-96.

Poore, G.C.B. (1994): A phylogeny of the families of Thalassinidea (Crustacea: Decapoda) with keys to families and genera. - Memoirs of the Victoria Museum, 54: 79120.

Rathbun, M.J. (1901): Investigations of the Aquatic Resources and Fisheries of Porto Rico by the United States Fish Commission Steamer Fish Hawk in 1899. The Brachyura and Macrura of Porto Rico. - Bulletins of the
United States Fish Commission 20 [for 1900, preprint dated 1901, published in journal in 1902]: 1-127.

Rathbun, M.J. (1935): Fossil Crustacea of the Atlantic and Gulf Coastal Plain. - Geological Society of America, Special Papers, 2: 1-160.

Rathbun, M.J. (1937): Cretaceous and Tertiary crabs from Panama and Colombia. - Journal of Paleontology, 11: 26-28.

Reboulet, S., Rawson, P.F., Moreno-Bedmar, J.A., Aguirre-Urreta, M.B., Barragán, R., Bogomolov, Y., Company, M., González-Arreola, C., Stoyanova, V.I., Lukeneder, A., Matrion, B., Mitta, V., Randrianaly, H. \& VAŠIČEK, Z. (2011): Report on the 4 the International Meeting of the IUGS Lower Cretaceous Ammonite Working Group, the "Kilian Group" (Dijon, France, 30th August 2010). - Cretaceous Research, 32: 786-793.

RoBert, E. (2002): La transgression albienne dans le Bassin Andin (Pérou): Biostratigraphie, Paléontologie (ammonites) et stratigraphie séquentielle. - Strata, 38: 1-380.

Robert, E. \& Bulot, L.G. (2004): Origin, phylogeny, faunal composition, and stratigraphical significance of the Albian engonoceratidae (pulchelliaceae, ammonitina) [sic] of Peru. - Journal of South American Earth Sciences, 17: 11-23.

Robles, R., Tudge, C.C., Dworschak, P.C., Poore, G.C.B. \& FELDER, D.L. (2009): Molecular phylogeny of the Thalassinidea based on nuclear and mitochondrial genes. - In: Martin, J.W., Crandall, K.A. \& Felder, D.L. (Eds.): Decapod crustacean phylogenetics [Crustacean Issues, vol. 18]: 309-326. Boca Raton, London \& New York (CRC Press \& Taylor \& Francis).

Rodrigues, S. DE A. \& Kensley, B. (1991): Eutrichocheles pindatyba, a new axiid shrimp (Crustacea: Decapoda: Thalassinidea) from Brazil. - Proceedings of the Biological Society of Washington, 104: 556-560.

Saint Laurent, M. DE (1973): Sur la systématique et la phylogénie des Thalassinidea: definition des families des Callianassidae et des Upogebiidae et de cinq genres nouveaux (Crustacea Decapoda). - Comptes Rendus hebdomadaires des Séances de I'Académie des Sciences, Paris, D277: 513-516.

Saint Laurent, M. DE (1979): Vers une nouvelle classification des Crustacés Décapodes Reptantia. - Bulletins de l'Office Nationale de Pêche de Tunisie, 3: 15-31.

SAKAI, K. (1992): The families Callianideidae and Thalassinidae, with the description of two new subfamilies, one new genus and two new species (Decapoda, Thalassinidea). - Naturalists, Publications of the Tokushima Biological Laboratory, Shikoku University, 4: 1-33.

SAKAI, K. (1994): Eleven species of Australian Axiidae (Crustacea: Decapoda: Thalassinidea) with descriptions of one new genus and five new species. - The Beagle, Records of the Museums and Art Galleries of the Northern Territory, 11: 175-202.

SAKAI, K. (1999): Redescription of Ctenocheles balssi KISHINOUYE, 1926, with comments on its systematic position and establishment of a new subfamily Gourretiinae (Decapoda, Callianassidae). - Crustaceana, 72: 85-97.

SAKAI, K. (2005): Callianassoidea of the world (Decapoda: Thalassinidea). - Crustaceana Monographs, 4: 1-285.

SAKAI, K. (2011): Axioidea of the world and a reconsidera- 
tion of the Callianassoidea (Decapoda, Thalassinidea, Callianassida). - Crustaceana Monographs, 13: 1-520.

SAKai, K. \& OHTA, S. (2005): Some thalassinid collections by R/V "Hakuhou-Maru” and R/V "Tansei-Maru”, University of Tokyo, in the Sulu Sea, Philippines, and in Sagami Bay and Suruga Bay, Japan, including two new species, one new genus, and one new family (Decapoda, Thalassinidea). - Crustaceana, 78: 67-93.

Sakai, K. \& de Saint Laurent, M. (1989): A check list of Axiidae (Decapoda, Crustacea, Thalassinidea, Anomura), with remarks and in addition descriptions of one new subfamily, eleven new genera and two new species. - Naturalists, Tokushima Biological Laboratory, Shikoku Women's University 3: 1-104.

Schweitzer, C.E. \& Feldmann, R.M. (2001): New Cretaceous and Tertiary decapod crustaceans from western North America. - Bulletins of the Mizunami Fossil Museum, 28: 173-210.

Schweitzer, C.E., Feldmann, R.M., Fam, J., Hessin, W.A., Hetrick, S.W., Nyborg, T.G. \& Ross, R.L.M. (2003): Cretaceous and Eocene Decapod Crustaceans from Southern Vancouver Island, British Columbia, Canada. - 66 pp.; Ottawa (NRC Research Press).

Schweitzer, C.E., Feldmann, R.M., Ćosović, V., Ross, R.L.M. \& Waugh, D.A. (2009): New Cretaceous and Eocene Decapoda (Thalassinidea, Brachyura) from British Columbia, Canada. - Annals of the Carnegie Museum, 77: 403-423.

Schweitzer, C.E., Feldmann, R.M., Garassino, A., Karasawa H. \& Schweigert, G. (2010): Systematic list of fossil decapod crustacean species. - Crustaceana Monographs, 10: 1-230.

Sinzowchweitzer, C.E., Feldmann, R.M. \& Lamanna, M.C. (2012): New genus of crab (Brachyura: Raninoida: Necrocarcinidae) from the Upper Cretaceous of West Antarctica, with description of a new species. - Annals of the Carnegie Museum, 80: 147-158.

SinZOw, I. (1908): Untersuchung einiger Ammonitiden aus dem Unteren Gault Mangyschlaks und des Kaukasus. - Verhandlungen der Kaiserlichen Russischen Mineralogischen Gesellschaft, 45: 455-519.

StenZel, H.B. (1945): Decapod crustaceans from the Cretaceous of Texas. - The University of Texas Publications, 4401: 401-477.

Toolson, E.K. \& KuEs, B.S. (1996): Decapod crustaceans from the Semilla Sandstone Member, Mancos Shale (Upper Cretaceous), North-Central New Mexico. Journal of Paleontology, 70: 111-116.

Tudge, C.C., Poore G.C.B. \& Lemaitre, R. (2000): Preliminary phylogenetic analysis of generic relationships within the Callianassidae and Ctenochelidae (Decapoda: Thalassinidea: Callianassoidea). - Journal of Crustacean Biology, 20 (Special Issue 2): 129-149.

Van Bakel, B.W.M., Guinot, D., Artal, P, Fraaije, R.H.B. \& JAGT, J.W.M. (2012): A revision of the Palaeocorystoidea and the phylogeny of raninoidian crabs (Crustacea, Decapoda, Brachyura, Podotremata). - Zootaxa, 3215: $1-216$.
Van Straelen, V. (1936): Crustacés Décapodes nouveaux ou peu connus de l'époque Crétacique. - Bulletins du Musée Royal d'Histoire Naturelle de Belgique, 12 (45): $1-49$.

Vega, F.J., Nyborg, T., Rojas-Briceño, A., Patarroyo, P., Luque, J., Porras-Múzquiz, H. \& Stinnesbeck, W. (2007): Upper Cretaceous Crustacea from Mexico and Colombia: similar faunas and environments during Turonian times. - Revista Mexicana de Ciencias Geológicas, 24: 403-422.

Vega, F.J., Nyborg, T., Kovalchuk, G., Luque, J., RojasBriceño, A., Patarroyo, P., Porras-Múzquiz, H., ArmsTrong, A., Bermúdez, H. \& Garibay, L. (2010): On some Panamerican Cretaceous crabs (Decapoda: Raninoida). - Boletín de la Sociedad Geológica Mexicana, 62: 263 279.

WANG, Y. (1981): Late Lower Cretaceous fossil Decapoda from Lhasa Region, Xizang. - The Series of the Scientific Expedition to the Qinhai Xizang Plateau [Palaeontology of Xizang], 3: 349-354; Beijing (Academia Sinica).

Withers, T.H. (1928): New Cretaceous crabs from England and Syria. - Annals and Magazine of Natural History, 10: $457-461$.

WoOdWARD, H. (1896): On some podophthalmatous Crustacea from the Cretaceous formation of Vancouver and Queen Charlotte Islands. - Quarterly Journal of the Geological Society of London, 52: 221-228.

Manuscript received: August 2nd, 2012.

Revised version accepted by the Stuttgart editor: October 12 th, 2012.

\section{Addresses of the authors:}

Hermann D. Bermúdez, Paleoexplorer S.A.S., Carrera 57, No. 134-20, Torre 3, apto. 902. Bogotá D.C., Colombia; e-mail: paleoexplorer@yahoo.com

Arley de J. Gomez-Cruz and Mario Moreno SÁnchez, Universidad de Caldas, Facultad de Ciencias, Departamento de Ciencias Geológicas, Calle 65 No. 26-10, Manizales, Colombia;

e-mail: arley.gomez@ucaldas.edu.co

Matúš HyžnÝ, Department of Geology and Paleontology, Faculty of Natural Sciences, Comenius University, Mlynská dolina G1, Bratislava, Slovakia;

e-mail: hyzny.matus@gmail.com

Josep A. Moreno-Bedmar, Ricardo Barragán and FranCISCO J. VEGA (corresponding author), Instituto de Geología, UNAM, Ciudad Universitaria, Coyoacán, México DF 04510, Mexico;

e-mail: vegver@unam.mx 